\title{
Long-term population trends reveal increasing importance of a Mediterranean wetland complex (Messolonghi lagoons, Greece) for wintering waterbirds
}

\author{
Vasilios Liordos ${ }^{1 *}$, Fotis Pergantis ${ }^{2}$, Iris Perganti ${ }^{2}$ and Yannis Roussopoulos ${ }^{3}$
}

\begin{abstract}
Background: The aim of this study was to present the first detailed analysis of long-term population estimates and trends of waterbirds wintering at Messolonghi lagoons, one of the largest Greek wetlands, during 1982 to 2012, using TrendSpotter software.

Results: The wetland supported on average 63,054 $\pm 22,241$ (SD) birds (range 29,630 to 109,795), with waterfowl and their allies being the most abundant group, by both species and numbers. Over $70 \%$ of the 28 most abundant species (19 waterfowl, 9 waders) were increasing (14 waterfowl, 6 waders), 4 waterfowl were decreasing, 3 species remained stable (1 waterfowl, 2 waders) and 1 wader could not be assessed. In total, waterfowl increased by 2\%, waders increased by $4 \%$ and the overall species assemblage increased by $2.2 \%$ over the 31 -year period. The wetland is of international importance for waterbirds in general and for Eurasian wigeon Anas penelope and Kentish plover Charadrius alexandrinus specifically. In addition, 7 other species (6 waterfowl, 1 wader) currently exceed the 1\% flyway population threshold and could also be considered as of international importance in the future.

Conclusions: Long-term increases in the numbers of most waterbirds were detected, and internationally important populations were identified, thus highlighting Messolonghi lagoons' increasing significance for wintering waterbirds over the past 31 years. Piscivores (i.e. pelicans, cormorants, herons and egrets), flamingos and small waders showed the strongest increases in numbers. In contrast, common pochard Aythya ferina and tufted duck Aythya fuligula showed the greatest declines. In most species, population trends followed those occurring at the flyway level, suggesting that regional or international rather than local factors may be mainly responsible.
\end{abstract}

Keywords: Midwinter counts; Waterfowl; Waders; Structural time series analysis; Ramsar criteria

\section{Background}

Waterbirds are a large and diverse group of birds which are ecologically dependent on aquatic habitats. The term 'waterbirds' initially referred to wildfowl (ducks, geese and swans) and large wading birds (such as herons and storks), but its meaning has expanded to include all the original waterfowl, seabirds and wading bird species (Gill 1994; Podulka et al. 2004). Wetlands are critical habitats for the fulfilment of the foraging, resting and breeding

\footnotetext{
*Correspondence: liordos@yahoo.com

'Department of Forestry and Natural Environment Management, Eastern Macedonia and Thrace Institute of Technology, 1st km Drama-Mikrohori, Drama 66100, Greece

Full list of author information is available at the end of the article
}

requirements of many waterbirds. Despite their importance for waterbirds, almost half of the world's natural wetlands have disappeared in the last century due to anthropogenic activities, while the other half have been variously affected (Shine and Klemm 1999). The continuing deterioration of wetlands and the consequent decline of many waterbird species' populations have rendered their protection and restoration a major conservation priority (Gill 1994; BirdLife International 2004). Migratory waterbirds and the wetland habitat that supports them are protected in European countries under international conventions (e.g. the Ramsar Convention) and legislation (e.g. the EU Wild Birds Directive, the EU Habitats Directive). 
The understanding of population dynamics in animals is a major topic in ecology, and bird species have been the subject of considerable research efforts (summarised by Perrins et al. 1993; Newton 1998). In the northern hemisphere, wintering waterbird populations are monitored by the International Waterbird Census (IWC) carried out under the auspices of Wetlands International (Rose and Scott 1997). These counts have suggested significant population trends (either increases or decreases) for almost half of all wintering waterbird populations in Europe (48\%), while the remaining are considered as stable or with uncertain trends (Wetlands International 2013). Several analyses of long-term trends of wintering waterbirds have been carried out in Europe, at a national, regional or site-specific level (e.g. Laursen and Frikke 2006; Crowe et al. 2008; Maclean et al. 2008; Nilsson 2008; Fouque et al. 2009; Musil et al. 2011).

Greece is located along the eastern Mediterranean migratory flyway and supports large numbers of migratory waterbirds during passage and for the duration of the wintering period. The country's mild climate, high diversity of wetland habitats and surrounding agricultural land provide refuge and feeding throughout winter. Importantly, when freezing conditions in parts of northeastern Europe and the Balkans may limit access to food resources, these factors make Greece particularly attractive for wintering waterbirds.

Greece's extensive coastline hosts several large wetlands, ten of which are protected under the Ramsar Convention for holding internationally important waterbird numbers, including the Messolonghi lagoons wetland complex (hereafter Messolonghi) in western Greece. Midwinter monitoring of waterbird populations is conducted annually since 1982 in all large Greek wetlands, and counts have been submitted for inclusion in the IWC. However, analyses of long-term changes in numbers of waterbirds in Greek wetlands are not currently available in the literature.

The aim of this study was therefore to present the first detailed analysis of midwinter counts of waterbirds wintering at Messolonghi, more specifically (1) to estimate the population size and assess the long-term trends in numbers of the most abundant waterbird species, as well as the whole species assemblage (Visser 2004a, b), (2) to calculate population alerts for declining species, at different intervals of the time series (Soldaat et al. 2007), and (3) to assess the site's international importance for waterbirds at both the specific and community levels (Wetlands International 2012, 2013).

\section{Methods}

\section{Study area}

Messolonghi is situated in western Greece, in the western part of Sterea Ellas Region, Aitoloakarnania Prefecture $\left(37^{\circ} 40^{\prime}\right.$ to $39^{\circ} 40^{\prime} \mathrm{N}, 20^{\circ} 10^{\prime}$ to $\left.21^{\circ} 30^{\prime} \mathrm{E}\right)$ and is one of the two largest Greek wetland complexes (Amvrakikos being the other one), totalling $258 \mathrm{~km}^{2}$ (Figure 1). This wetland complex is very important for some 173 wintering and breeding migratory bird species (Zalidis and Mantzavelas 1994) and was therefore designated as a Ramsar site in 1975 and a National Park in 2006. It is also a Special Protection Area (SPA) and a proposed Natura 2000 site.

The site was formed by the action of two rivers: the Acheloos to the west and Evinos to the east, and occupies an extensive coastal zone with a wetland complex consisting of a double delta formed by Acheloos and Evinos rivers, extensive lagoons and salt marshes, restricted freshwater marshes, relicts of a riparian forest, coastal spits with dune formations, saltworks and scattered rocky hills in and around the area (Pergantis and Handrinos 1992; Zalidis and Mantzavelas 1994). The Messolonghi lagoon (11,200 ha) predominates in the centre of the wetland complex, whereas other large lagoons are the Aitoliko lagoon (1,400 ha) to the north, the Klissova lagoon (3,000 ha) to the east, and the Gourounopoules and Tholi lagoons (800 ha) to the west. All the lagoons are shallow with a maximum depth of $1.5 \mathrm{~m}$, with the exception of the Aitoliko lagoon with a maximum depth of $30 \mathrm{~m}$, although with shallow parts. The local tidal range is small varying between 0.30 and $0.40 \mathrm{~m}$ (European Sea Level Service).

The major land uses in the area are fishing and salt production. The Messolonghi wetland complex is one of the most productive fishing grounds in Greece, because of the local climate, topography and morphology. Traditional fishing by co-operatives and private fishermen is extended in a surface of 15,000 ha, and the total annual production amounts about 800 to 1,000 tons. The most important marketed species are gilthead seabream Sparus aurata, European sea bass Dicentrarchus labrax, European eel Anguilla anguilla and several species of the Mugilidae family. Saltworks occupy a surface of 12,400 ha. Other important land uses are crop cultivation in drained land (clover, maize, cotton) and livestock grazing (cattle, sheep, goats). Illegal resort house building, especially along coastal stripes and sand dunes, illegal hunting and intensive fishing techniques are among the main activities adversely affecting the wetland's habitats and their associated avifauna.

\section{Data collection}

The dataset includes IWC results from Messolonghi. The IWC is conducted in mid-January each year, when peak numbers of most species are present, and it is implemented by the Hellenic Ornithological Society (HOS). Counts are conducted by HOS professional staff and amateur volunteers on predetermined dates announced by the national coordinators to minimise the risk of double counts arising from bird movements within and 


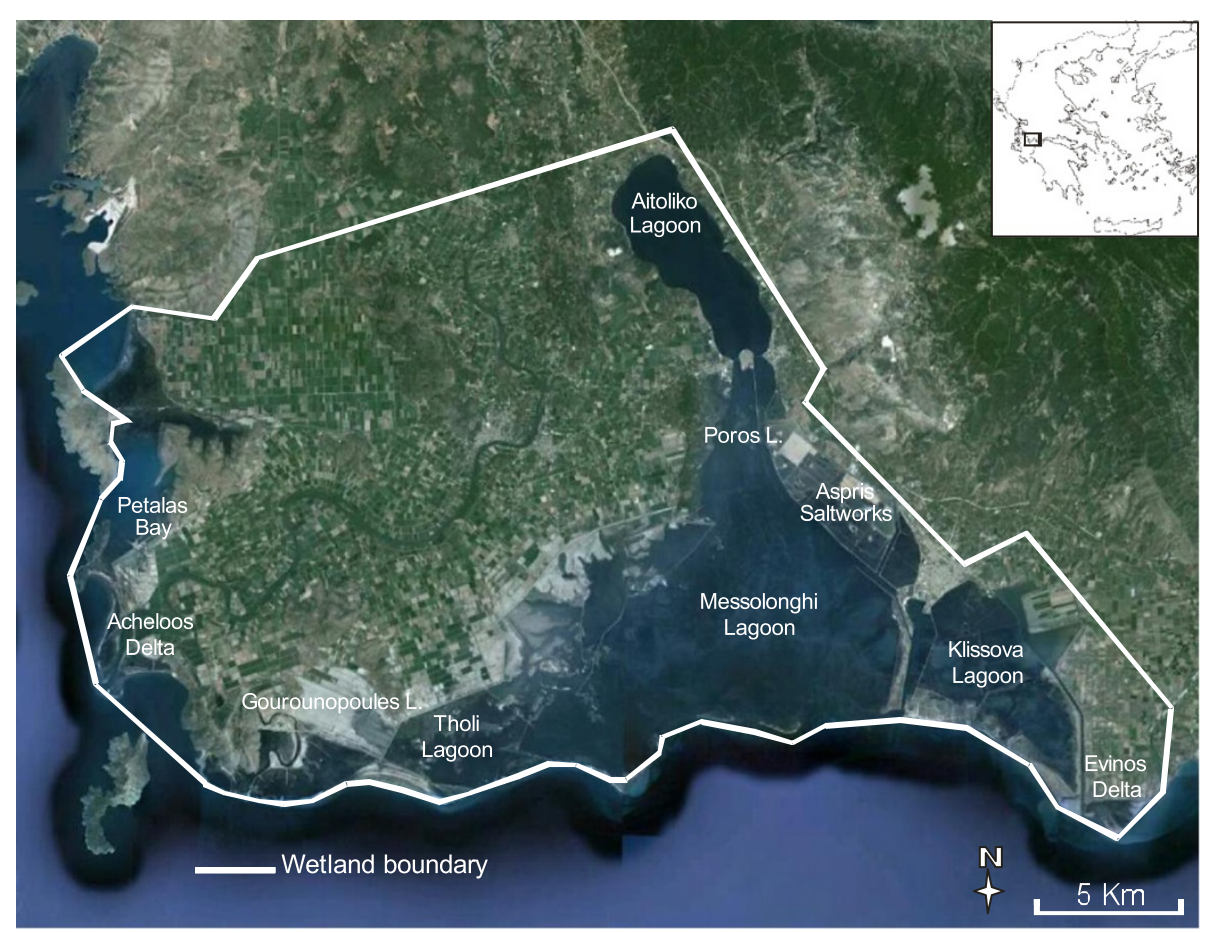

Figure 1 Messolonghi lagoons wetland complex: site boundaries and main wetland habitats. Satellite image taken from Google Earth (Image ๑ 2013 TerraMetrics, ๑ 2013 DigitalGlobe, @ 2013 Google Inc.).

between sites, thus allowing for straightforward and valid comparisons between sites and years (Wetlands International 2010). The wetland complex has been divided into 21 suitable sectors to allow for the monitoring of all available habitats, namely lagoons, open sea, saltworks, rivers and estuaries, salt marshes, mudflats, reed beds, adjacent cultivated and fallow land, ditches and halophytic grassland. Five two-member groups are assigned to several sectors, and counts are carried out in a single day, from dusk to dawn. The standardised 'ground counts' methodology is followed according to the guidelines of Wetlands International (2010). Predetermined vantage points are approached by car, selected so that each sector is completely scanned and without overlap of areas counted.

The midwinter counts methodology presents several shortcomings: (a) population maxima may occur on earlier or later dates, (b) several duck species may disperse far at sea and become invisible from land, (c) some species, such as little grebe Tachybaptus ruficollis, northern lapwing Vanellus vanellus, Eurasian golden plover Pluvialis apricaria and Eurasian curlew Numenius arquata in certain years might be hidden in vegetation during the counts. In addition, waders are sometimes best counted when concentrated at high-tide roosts. However, the local tidal range is small and intertidal areas are not extensive; thus, waders are usually within identification and counting range. In conclusion, it is not possible to count every individual in a population, and consequently, midwinter counts cannot usually be used to determine absolute population sizes. However, as the same sectors are counted in the same way every year, the proportion of the population of each species represented by the counted sample varies little from year to year. Therefore, estimated numbers are suitable for the calculation of population trends and the assessment of the site's importance for waterbirds.

During 1982 to 2012, the 28 most abundant waterbird species were included in the time series dataset and were grouped into two main categories: waterfowl and their allies (19 species, including ducks, coots, grebes, pelicans, cormorants, herons and egrets, spoonbills and flamingos) and waders (9 species, including Recurvirostridae, Charadriidae and Scolopacidae). All 28 species were present during the whole time series (since 1982; 31 years), with the exception of Dalmatian pelican Pelecanus crispus (since 1984; 29 years), greater flamingo Phoenicopterus roseus (since 1988; 25 years) and pied avocet Recurvirostra avosetta (since 1985; 28 years), with no missing values after the first occurrence. Species excluded from the analysis occurred in low numbers (less than 50 individuals in any year) and during a few years (less than 20 wintering seasons). Gulls and terns were not included in the analysis since they were not intensively monitored, especially in the early years, and (for the gulls at least) their distributions are generally too 
widespread for adequate monitoring by this method alone.

\section{Data analysis}

Long-term population trends of the 28 waterbird species were assessed with the statistical software TrendSpotter 6.4 (Visser 2004a, b; Soldaat et al. 2007). TrendSpotter uses a smoothing method for analysing environmental time series, based on structural time series analysis in combination with the Kalman filter, and it is the method of choice to smooth time series that contain only one value per time point, as in this study (Soldaat et al. 2007). This software estimates smoothed population numbers and their standard deviations and allows the estimation of confidence intervals based on the deviations of time point values from the smoothed line. It is then possible to test the difference between the smoothed population number of the last year of a time series against each of the preceding years (total change rate (TCR)), taking into account serial correlation. Mean yearly change rate (YCR) estimates, i.e. the TCR expressed as a mean change rate per year, and confidence intervals could then be used to classify the trends per year in six categories: strong increase (lower confidence limit $(\mathrm{CL})>$ 1.05), moderate increase $(1<$ lower $\mathrm{CL} \leq 1.05)$, stable (confidence interval $(\mathrm{CI})$ contains 1.00 and lower $\mathrm{CL} \geq 0.95$ and upper $\mathrm{CL} \leq 1.05)$, moderate decline $(0.95 \leq$ upper $\mathrm{CL}<$ 1.00), steep decline (upper $\mathrm{CL}<0.95$ ) and uncertain (CI contains 1.00 and [lower $\mathrm{CL}<0.95$ or upper $\mathrm{CL}>1.05$ ]). For further details on TCR and YCR calculations and trend classification, see Soldaat et al. (2007). All data counts were ln-transformed prior to the analysis to achieve normality. All graphs for the statistical testing of normality, the occurrence of cycles and the dependence of consecutive residuals, as well as for the presentation of the smoothed trend line with its associated 95\% CI, were produced with the S-PLUS 6.2 statistical package (Insightful Corp., Seattle, WA, USA) according to Visser (2004a).

The British Trust for Ornithology uses a population alert system to highlight declines in bird numbers, with strong declines $(>50 \%)$ and moderate declines $(>25 \%)$ as alert thresholds over specifically defined time periods (Atkinson et al. 2006). TrendSpotter was also used to calculate population alerts for identified declining species, through the conversion of the TCR values: an upper TCR CL lower than 0.75 or lower than 0.50 represents an alert threshold of $25 \%$ and $50 \%$, respectively (Soldaat et al. 2007). Population alerts were calculated for declining species over the whole time series (31 years) and the last 20 and 10 years.

The international importance of Messolonghi for waterbirds was assessed by comparing their numbers with the Ramsar Convention specific criteria for waterbirds (Wetlands International 2012): a wetland should be considered internationally important if it regularly supports $\geq 20,000$ waterbirds (criterion 5 ) or if it regularly supports $1 \%$ of the individuals in a population of one species or subspecies of waterbirds (criterion 6). According to Wetlands International (2012) 'a wetland regularly supports a population of a given size if the requisite number of birds is known to have occurred in two thirds of the seasons for which adequate data are available, the total number of seasons being not less than three.' The species-specific $1 \%$ flyway population thresholds for criterion 6 are given by Wetlands International (2013) (Table 1).

\section{Results}

\section{Population estimates}

Messolonghi hosted on average $63,054 \pm 22,241$ (SD) wintering waterbirds (range 29,630 to 109,795) during this 31-year period (Table 1). Waterfowl and their allies were the most abundant group wintering at Messolonghi, by both species and numbers (Table 1). Eurasian coot Fulica atra, Eurasian wigeon Anas penelope, common teal Anas crecca and common pochard Aythya ferina were the most numerous waterfowl species. Among the waders, the most numerous were dunlin Calidris alpina, Kentish plover Charadrius alexandrinus, little stint Calidris minuta and northern lapwing.

\section{Population trends}

The analysis of long-term population trends for the 28 most numerous wintering waterbird species at Messolonghi showed that 20 (14 waterfowl, 6 waders) were increasing and only 4 (all waterfowl) were decreasing (Table 2, Figure 2). The trend of three species was assessed as 'stable' (Eurasian wigeon, northern lapwing, Eurasian curlew), and the trend of one species was assessed as 'uncertain' (dunlin). Among the waterfowl, Dalmatian pelican, great cormorant Phalacrocorax carbo, little egret Egretta garzetta, great egret Casmerodius albus, grey heron Ardea cinerea and greater flamingo increased by more than $5 \%$ per year. On the other hand, the greatest declines $(>5 \%$ per year) were found for common pochard and tufted duck Aythya fuligula. The greatest increases among the waders $(>5 \%$ per year) included pied avocet, Kentish plover, grey plover Pluvialis squatarola, Eurasian golden plover, northern lapwing and little stint. Combined estimates showed that there was a moderate annual increase in the total number of waterfowl (2\%), waders (4\%) and the overall waterbird species assemblage (2.2\%) at Messolonghi between 1982 and 2012 (Table 2, Figure 3).

Calculation of population alerts for the four declining waterfowl species showed that the tufted duck population was declining by more than 50\% during the entire study period and during the last 20 and 10 years (Table 3). Population alerts were also found for common 
Table 1 Population data for the 28 most abundant waterbird species wintering at the Messolonghi lagoons during 1982 to 2012

\begin{tabular}{|c|c|c|c|c|c|c|c|}
\hline \multirow[t]{2}{*}{ Species name } & \multicolumn{4}{|c|}{ Biogeographic population (flyway/region) } & \multicolumn{3}{|c|}{ Messolonghi lagoons population } \\
\hline & Name & Estimate & $1 \%$ threshold & Assessment & Mean \pm SD & Range & Ramsar $^{\mathrm{e}}$ \\
\hline Great crested grebe & Black Sea, Mediterranean (w) & 580,000 to 870,000 & 7,100 & Decreasing & $832 \pm 749$ & 47 to 3,205 & 0 \\
\hline Black-necked grebe & Europe/S, W Europe and N Africa & 159,000 to 268,000 & 2,100 & Decreasing & $567 \pm 575$ & 21 to 2,862 & 1 \\
\hline Little grebe & Europe, NW Africa & 300,000 to 510,000 & 3,900 & Increasing & $453 \pm 347$ & 62 to 1,113 & 0 \\
\hline Dalmatian pelican & Black Sea, Mediterranean (w) & 6,600 to 6,800 & 65 & Increasing & $65 \pm 76$ & 0 to 256 & $10^{f}$ \\
\hline Great cormorant & Black Sea, Mediterranean & 350,000 to 450,000 & 4,000 & Increasing & $2,913 \pm 2,081$ & 395 to 5,980 & $13^{f}$ \\
\hline Little egret & $\begin{array}{l}\text { Central, E Europe/Black Sea, } \\
\text { E Mediterranean }\end{array}$ & 44,000 to 72,400 & 560 & Stable & $356 \pm 271$ & 8 to 1,050 & $8^{f}$ \\
\hline Great egret & $\begin{array}{l}\text { W, Central, SE Europe/Black Sea, } \\
\text { Mediterranean }\end{array}$ & 38,800 to 54,300 & 460 & Increasing & $305 \pm 218$ & 7 to 927 & $7^{f}$ \\
\hline Grey heron & Central, E Europe $\mathrm{a}^{\mathrm{a}}$ & 189,000 to 256,000 & 2,200 & Increasing & $182 \pm 140$ & 5 to 500 & 0 \\
\hline Eurasian spoonbill & $\begin{array}{l}\text { Central, SE Europe/Mediterranean, } \\
\text { tropical Africa }\end{array}$ & 11,600 to 11,700 & 120 & Decreasing & $54 \pm 56$ & 6 to 219 & 3 \\
\hline Greater flamingo & E Mediterranean & 60,000 & 600 & Stable & $1,760 \pm 2,417$ & 1 to 8,360 & $13^{f}$ \\
\hline Common shelduck & Black Sea, Mediterranean & 120,000 & 1,200 & Increasing & $399 \pm 458$ & 42 to 2,270 & 3 \\
\hline Mallard & E Europe/Black Sea, E Mediterranean & $2,000,000$ & 20,000 & Decreasing & $563 \pm 634$ & 5 to 2,500 & 0 \\
\hline Northern pintail & $\begin{array}{l}\text { W Siberia, NE, E Europe/S Europe, } \\
\text { W Africa }\end{array}$ & 750,000 & 7,500 & Fluctuating & $913 \pm 799$ & 30 to 2,500 & 0 \\
\hline Northern shoveler & $\begin{array}{l}\text { W Siberia, NE, E Europe/S Europe, } \\
\text { W Africa }\end{array}$ & 450,000 & 4,500 & Increasing & $2,070 \pm 1,602$ & 10 to 6,665 & 3 \\
\hline Eurasian wigeon & $\begin{array}{l}\text { W Siberia, NE Europe/Black Sea, } \\
\text { Mediterranean }\end{array}$ & 300,000 & 3,000 & Stable & $8,032 \pm 3,303$ & 2,563 to 15,600 & 30 \\
\hline Common teal & $\begin{array}{l}\text { W Siberia, NE Europe/Black Sea, } \\
\text { Mediterranean }\end{array}$ & 750,000 to $1,380,000$ & 10,200 & Increasing & $5,048 \pm 3,987$ & 30 to 20,770 & 1 \\
\hline Common pochard & $\begin{array}{l}\text { Central, NE Europe/Black Sea, } \\
\text { Mediterranean }\end{array}$ & 800,000 & 8,000 & Decreasing & $4,574 \pm 5,305$ & 90 to 20,000 & 4 \\
\hline Tufted duck & $\begin{array}{l}\text { Central Europe/Black Sea, } \\
\text { Mediterranean (w) }\end{array}$ & 600,000 & 6,000 & Decreasing & $442 \pm 1,002$ & 0 to 4,000 & 0 \\
\hline Eurasian coot & Black Sea, Mediterranean (w) & $2,500,000$ & 25,000 & Increasing & $20,884 \pm 10,878$ & 7,220 to 42,435 & $11^{f}$ \\
\hline Pied avocet & SE Europe/Black Sea, Turkey (br) & 47,000 & 470 & Decreasing & $625 \pm 456$ & 16 to 1,435 & $14^{f}$ \\
\hline Kentish plover & Black Sea, E Mediterranean/E Sahel & 32,000 to 49,000 & 400 & Unknown & $1,854 \pm 1,436$ & 31 to 5,150 & 22 \\
\hline Grey plover & $\begin{array}{l}\text { W Siberia, Canada/W Europe, } \\
\text { W Africa }\end{array}$ & 250,000 & 2,500 & Decreasing (?) & $105 \pm 64$ & 2 to 205 & 0 \\
\hline Eurasian golden plover & N Europe/W Europe, NW Africa ${ }^{\mathrm{b}}$ & 500,000 to $1,000,000$ & 7,100 & Increasing & $1,357 \pm 882$ & 110 to 3,780 & 0 \\
\hline Northern lapwing & W Asia/SW Asia, Europe, W Asia (br) & $5,500,000$ to $9,500,000$ & 72,300 & Stable & $1,818 \pm 1,537$ & 120 to 6,940 & 0 \\
\hline Dunlin & $\begin{array}{l}\text { NE Europe, NW Siberia/W Europe, } \\
\text { NW Africac }\end{array}$ & $1,330,000$ & 13,300 & Stable & $5,071 \pm 2,923$ & 720 to 10,800 & 0 \\
\hline
\end{tabular}


Table 1 Population data for the 28 most abundant waterbird species wintering at the Messolonghi lagoons during 1982 to 2012 (Continued)

\begin{tabular}{|c|c|c|c|c|c|c|c|}
\hline Little stint & N Europe/S Europe, $N$ and W Africa & 300,000 & 3,000 & Increasing (?) & $1,820 \pm 1,667$ & 10 to 5,890 & 7 \\
\hline Common redshank & Central, E Europe (br) ${ }^{d}$ & 570,000 to 870,000 & 7,000 & Decreasing & $1,015 \pm 770$ & 65 to 3,870 & 0 \\
\hline Eurasian curlew & Europe, $\mathrm{N}$ and $\mathrm{W}$ Africa & 700,000 to $1,000,000$ & 8,400 & Decreasing & $177 \pm 105$ & 15 to 487 & 0 \\
\hline Overall waterbirds & & & & & $63,054 \pm 22,241$ & 29,630 to 109,795 & 31 \\
\hline
\end{tabular}

Biogeographic population data is taken from Wetlands International (2013). Waterbird population estimates (mean $\pm S D$, range) and the number of years in which Ramsar population criteria were met are also

presented. ${ }^{a}$ Some migrate $\mathrm{S}$ in the non-breeding period. ${ }^{\mathrm{b}}$ Non-breeding range $\mathrm{W}$ and $\mathrm{S}$ Continental Europe, E Britain, NW Africa. 'Non-breeding range W Europe, Mediterranean, $\mathrm{N}$ and $\mathrm{W}$ Africa. ${ }^{\mathrm{d}}$ Non-breeding range $\mathrm{E}$ Mediterranean, Asia Minor, Sub-Saharan Africa. ${ }^{~}$ Number of years in which Ramsar criteria 5 (waterbird species assemblage exceeded 20,000 individuals) and 6 (single species numbers exceeded the 1\% flyway population threshold) were met. Internationally important populations are indicated in italics. ${ }^{f}$ Single species populations currently exceeding the $1 \%$ threshold that could be assessed as internationally important in the future. w, wintering; br, breeding; ?, uncertain. 
Table 2 Population trends for selected waterbird species wintering at the Messolonghi lagoons during 1982 to 2012

\begin{tabular}{|c|c|c|c|}
\hline Species name & YCR & $\mathrm{Cl}_{\mathrm{YCR}}$ & Trend classification \\
\hline Great crested grebe & 1.050 & 1.019 to 1.081 & $\uparrow$ \\
\hline Black-necked grebe & 0.944 & 0.901 to 0.989 & $\downarrow$ \\
\hline Little grebe & 1.054 & 1.024 to 1.084 & $\uparrow$ \\
\hline Dalmatian pelican & 1.095 & 1.074 to 1.117 & $\uparrow \uparrow$ \\
\hline Great cormorant & 1.088 & 1.083 to 1.093 & $\uparrow \uparrow$ \\
\hline Little egret & 1.127 & 1.111 to 1.144 & $\uparrow \uparrow$ \\
\hline Great egret & 1.101 & 1.083 to 1.120 & $\uparrow \uparrow$ \\
\hline Grey heron & 1.125 & 1.105 to 1.145 & $\uparrow \uparrow$ \\
\hline Eurasian spoonbill & 1.072 & 1.025 to 1.120 & $\uparrow$ \\
\hline Greater flamingo & 1.397 & 1.344 to 1.453 & $\uparrow \uparrow$ \\
\hline Common shelduck & 1.059 & 1.018 to 1.102 & $\uparrow$ \\
\hline Mallard & 1.065 & 1.018 to 1.114 & $\uparrow$ \\
\hline Northern pintail & 0.956 & 0.920 to 0.993 & $\downarrow$ \\
\hline Northern shoveler & 1.071 & 1.037 to 1.106 & $\uparrow$ \\
\hline Eurasian wigeon & 1.006 & 0.992 to 1.020 & $\leftrightarrow$ \\
\hline Common teal & 1.039 & 1.008 to 1.071 & $\uparrow$ \\
\hline Common pochard & 0.897 & 0.853 to 0.944 & $\downarrow \downarrow$ \\
\hline Tufted duck & 0.725 & 0.655 to 0.801 & $\downarrow \downarrow$ \\
\hline Eurasian coot & 1.024 & 1.009 to 1.039 & $\uparrow$ \\
\hline Overall waterfowl & 1.020 & 1.007 to 1.033 & $\uparrow$ \\
\hline Pied avocet & 1.153 & 1.124 to 1.183 & $\uparrow \uparrow$ \\
\hline Kentish plover & 1.126 & 1.073 to 1.182 & $\uparrow \uparrow$ \\
\hline Grey plover & 1.104 & 1.060 to 1.150 & $\uparrow \uparrow$ \\
\hline Eurasian golden plover & 1.079 & 1.056 to 1.103 & $\uparrow \uparrow$ \\
\hline Northern lapwing & 0.987 & 0.956 to 1.019 & $\leftrightarrow$ \\
\hline Dunlin & 1.028 & 0.999 to 1.058 & $?$ \\
\hline Little stint & 1.102 & 1.052 to 1.154 & $\uparrow \uparrow$ \\
\hline Common redshank & 1.035 & 1.014 to 1.056 & $\uparrow$ \\
\hline Eurasian curlew & 1.006 & 0.968 to 1.045 & $\leftrightarrow$ \\
\hline Overall waders & 1.040 & 1.026 to 1.054 & $\uparrow$ \\
\hline Overall waterbirds & 1.022 & 1.011 to 1.033 & $\uparrow$ \\
\hline
\end{tabular}

Yearly change rate $(\mathrm{YCR})$, its $95 \%$ confidence interval $\left(\mathrm{Cl}_{Y C R}\right)$ and the associated trend classification are presented. $\uparrow \uparrow$, strong increase; $\uparrow$, moderate increase; $\leftrightarrow$ stable; $\downarrow$, moderate decline; $\downarrow \downarrow$, steep decline; ?, uncertain. The overall values are in italics.

pochard, northern pintail Anas acuta and black-necked grebe Podiceps nigricollis during most of the specified periods, with the exception of the whole time series for northern pintail.

\section{Site importance for waterbirds}

The examination of the total numbers of the waterbird species assemblage (Table 1, Figure 3) reveals that Messolonghi supported in each of the monitored years more than 20,000 individuals and thus fulfils the Ramsar Convention's criterion 5 . The wetland should therefore be considered internationally important for waterbirds. The numbers of Eurasian wigeon and Kentish plover can be considered of international importance since they exceed the $1 \%$ threshold during the major part $(>2 / 3)$ of the period. In addition, the numbers of Dalmatian pelican, great cormorant, little egret, great egret, greater flamingo, Eurasian coot and pied avocet could also be considered as of international importance in the future since they have exceeded the $1 \%$ threshold during the last 5 to 12 years (Table 1, Figure 2).

\section{Discussion}

Over 70\% of waterbird species wintering at Messolonghi displayed increasing trends. The trends found in this study were compared to similar analyses available for a range of other European countries: Bulgaria (Michev and Profirov 2003), Sweden (Nilsson 2008), Ireland (Crowe et al. 2008), the Netherlands (Hustings et al. 2009), France (Fouque et al. 2009), the UK (Calbrade et al. 2010), Portugal (Catry et al. 2011), the Czech Republic (Musil et al. 2011), Denmark, Germany and the Netherlands (Wadden Sea; Van Roomen et al. 2012), and as found in this study, the number of increasing species was higher than the number of decreasing species in Bulgaria, Sweden, the Netherlands (part), France, the UK and the Czech Republic. In contrast, decreasing species were in the majority in the Irish and Wadden Sea (German/Danish/Dutch) studies.

In general, for 18 waterbird species wintering at Messolonghi, the changes in numbers are consistent with those occurring at the flyway level (see Tables 1 and 2; Wetlands International 2013). This suggests that in these cases the factors affecting waterbird numbers are regional or international rather than local. However, for nine species, differences between the flyway trend and the trend at Messolonghi were observed, suggesting that site-specific factors may be significant for these species.

In the waterfowl and allies group, 13 species show similar and 5 species different trends to those observed at the flyway level. Excluding wildfowl, black-necked grebe was the only declining species in the waterfowl and allies group, and for that reason, population alerts were generated. In contrast, great crested grebe Podiceps cristatus, little grebe and Eurasian spoonbill Platalea leucorodia populations showed a moderate rate of increase, while Dalmatian pelican, great cormorant, little egret, great egret, grey heron and greater flamingo showed the most remarkable increases in numbers. This pattern is similar to that observed at both the flyway level and across Europe (BirdLife International 2004; Wetlands International 2013).

Dalmatian pelican populations suffered a massive decline during the nineteenth and twentieth centuries, primarily caused by wetland drainage, shooting and 


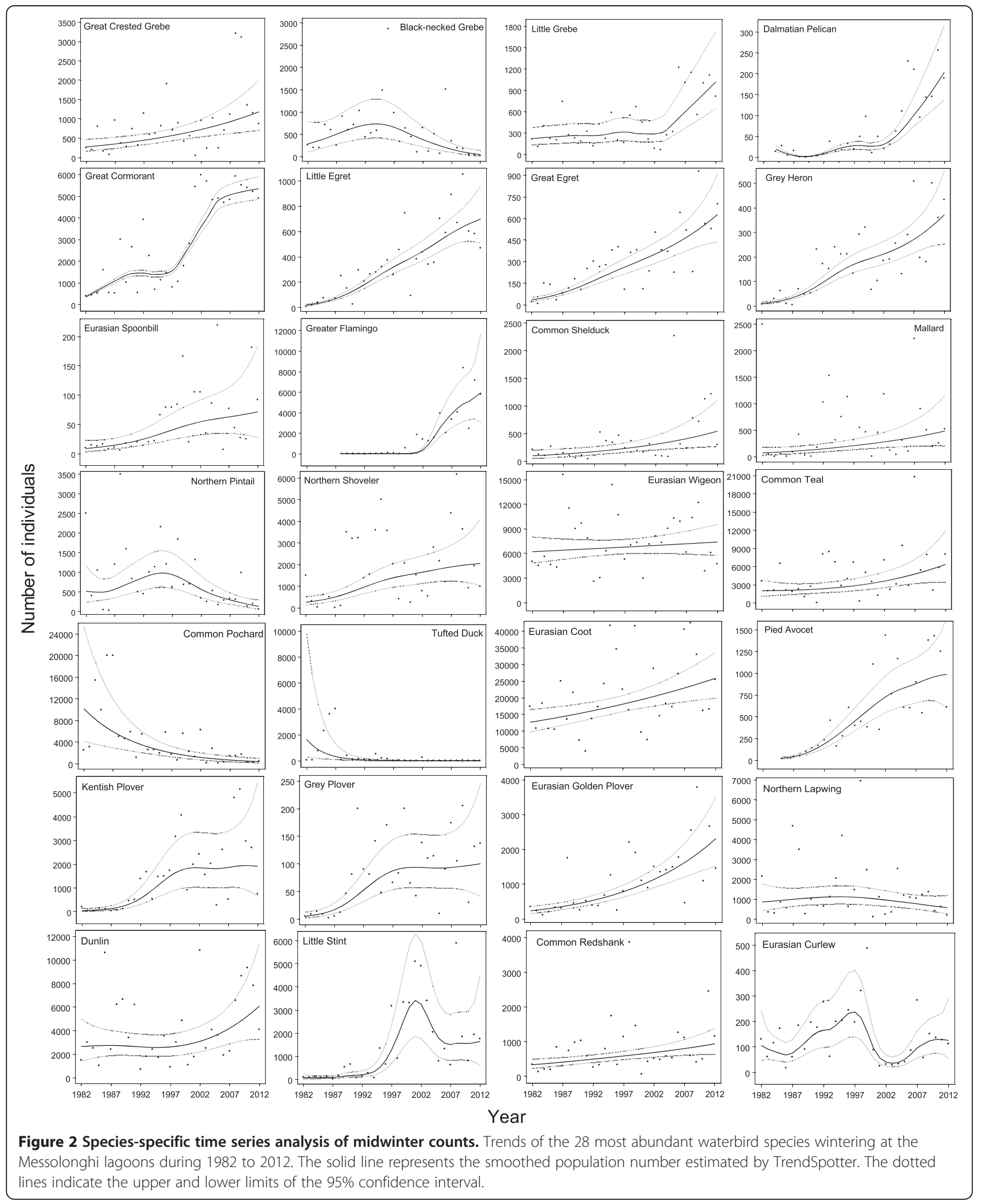




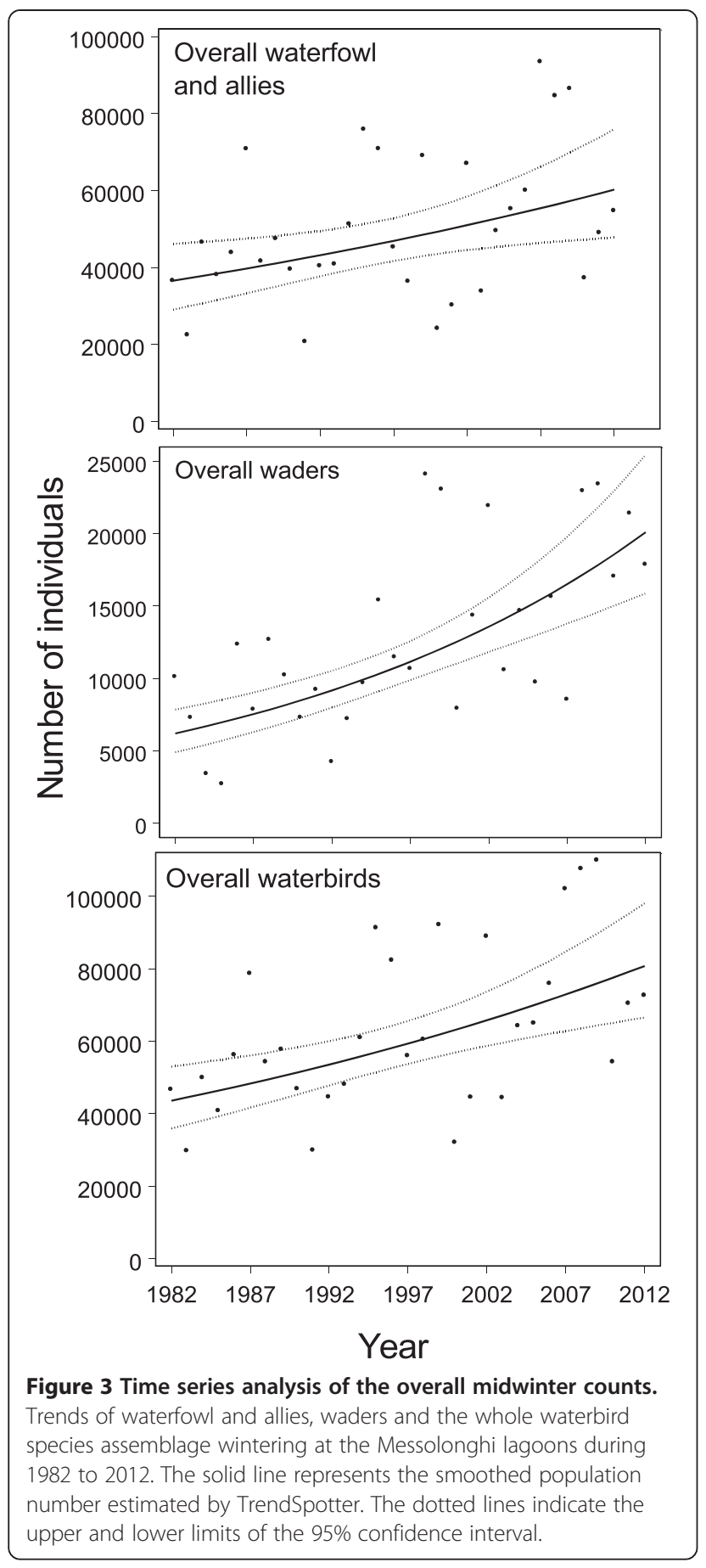

persecution by fishermen (Crivelli et al. 1997; Mix and Bräunlich 2000). Since the cessation of that decline, the flyway population has increased mainly due to the implementation of conservation actions, particularly at Lake Mikri Prespa in Greece, the species' largest colony and also in other countries (BirdLife International 2012). However, rapid population declines in the remainder of its range are suspected to be continuing,
Table 3 Population alerts for declining waterbird species wintering at the Messolonghi lagoons during 1982 to 2012

\begin{tabular}{lccc}
\hline Species name & 1982 & 1993 & 2003 \\
\hline Black-necked grebe & Moderate alert & Strong alert & Strong alert \\
Northern pintail & No alert & Strong alert & Moderate alert \\
Common pochard & Strong alert & Strong alert & Moderate alert \\
Tufted duck & Strong alert & Strong alert & Strong alert \\
\hline
\end{tabular}

Alerts were generated over the whole time series and the last 20 and 10 years. Moderate alerts correspond to $>25 \%$ decline; strong alerts correspond to $>50 \%$ decline.

and therefore, the species is still listed as 'vulnerable' (BirdLife International 2012).

Great cormorant and heron species have been variably but widely persecuted in Europe, due to their fish-eating habits (Van Eerden et al. 1995; Kushlan and Hancock 2005). Declines in Europe were observed in the twentieth century, but these species' populations are now mostly increasing at the flyway level (Marion 2003; Kushlan and Hancock 2005). These increases have mainly been attributed to the legal protection of the species and their habitats and the increase in fish productivity due to eutrophication of aquatic habitats (Van Eerden et al. 1995; BirdLife International 2004; Kushlan and Hancock 2005).

Greater flamingo has also shown a significant increase in numbers during the 31-year study period. It was first recorded in Greece in the 1830s, but until the early 1980s, there were fewer than 30 records of single individuals or very small flocks from the entire country (Handrinos and Akriotis 1997). The species first appeared at Messolonghi in 1988, and its population developed from a few individuals in the 1990s to several thousands in the 2000s, a trend similar to that observed in other Greek wetlands (Handrinos and Akriotis 1997; HOS, unpublished data). The southwest Asian population of greater flamingo is currently stable, whereas the West Mediterannean population is currently increasing, mainly due to the protection of breeding sites (Martos and Johnson 1996; Miltiadou 2005). It has been demonstrated by band re-sightings that the East Mediterranean population receives influxes from both the West Mediterranean and southwest Asia (Handrinos and Akriotis 1997; Balkiz et al. 2007; FP and VL, personal observation), which have probably contributed to the increase of the Messolonghi wintering population.

Despite its small size, Greece is one of the most important countries in the eastern Mediterranean-Black Sea region for the wintering populations of wildfowl and Eurasian coot (Athanassiou 1987), holding an average number of 345,000 birds per year during 1982 to 1992 (Handrinos and Akriotis 1997). Results from Messolonghi show that it is among the most important Greek wetlands for wintering ducks and Eurasian coot, with an average of about 43,000 birds per year during 1982 to 
2012, supporting especially high numbers of Eurasian coot and Eurasian wigeon. Eurasian wigeon did not show any significant trends over the entire study period, whereas common shelduck Tadorna tadorna, mallard Anas platyrhynchos, northern shoveler Anas clypeata, common teal and Eurasian coot moderately increased their numbers. In contrast, northern pintail, common pochard and tufted duck declined in numbers, and strong and/or moderate alerts were triggered for the last three decades. With the exception of mallard, trends were similar to those observed at the flyway level, suggesting that regional or international rather than local factors may be mostly responsible for the changes in numbers of ducks at Messolonghi. Many factors have been reported to negatively affect duck species worldwide at both a site and flyway level, such as breeding and wintering habitat degradation and loss due to oil pollution, drainage, eutrophication, agricultural intensification and industrial development, hunting disturbance, lead shot poisoning and avian influenza outbreaks (del Hoyo et al. 1992; Mateo et al. 1998; Kear 2005; Melville and Shortridge 2006). Furthermore, in recent decades, the influence of global climate change has been implicated in the 'short stopping' of migratory bird populations where wintering conditions closer to breeding areas may have become more favourable during the winter period, thus enabling a range of species to reduce migration distance (Scott and Rose 1996; Snow and Perrins 1998; Dalby et al. 2013; Lehikoinen et al. 2013). Lehikoinen et al. (2013) demonstrated strong northeastwards shifts in the centres of gravity of the entire wintering range of three common waterbird species, including tufted duck, along the North-West European flyway during the past three decades. Dalby et al. (2013) found that temperature clearly plays a role in shaping the winter distribution of six dabbling duck species but concluded that other factors, probably related to feeding ecology, may also influence their distributions.

Wader populations have become increasingly important at Messolonghi. Of the nine most abundant species, five showed a significant increase (pied avocet, Kentish plover, grey plover, Eurasian golden plover, little stint), whereas the rest (northern lapwing, dunlin, common redshank Tringa totanus, Eurasian curlew) remained relatively stable or fluctuating. These trends contrast somewhat with those at the flyway level where only Eurasian golden plover and little stint are increasing. Wader species populations are generally decreasing at a global level (IUCN 2012), mainly due to the degradation and loss of their habitats through mostly agricultural intensification, wetland drainage and reclamation of intertidal mudflats from infrastructure development (del Hoyo et al. 1992; Burton et al. 2002). The loss of habitat due to land reclamation for agricultural or industrial use, illegal hunting and illegal building of resort housing have been identified as the main factors threatening wader populations at Messolonghi (de Nobel 1995; Handrinos and Akriotis 1997). However, despite these activities and the global trends, it is remarkable that wader populations are generally increasing in the study area, at both the site- and species-specific levels, perhaps suggesting that the relative conservation value of Messolonghi is increasing.

Messolonghi is of international importance for waterbirds in general and for Eurasian wigeon and Kentish plover in particular. Furthermore, recent years' counts indicate that its international importance will probably increase in the future due to the increasing numbers of several species.

\section{Conclusions}

As a whole, the waterbird species assemblage wintering at Messolonghi lagoons in 1982 to 2012 showed a moderate increase. At the species level, most waterbirds were also increasing, with piscivores (Dalmatian pelican, great cormorant, little egret, great egret, grey heron), greater flamingo and small waders showing the strongest longterm increases. In contrast, the greatest long-term declines were found for two diving duck species: common pochard and tufted duck. Furthermore, the wetland complex is of international importance for waterbirds in general and for two species specifically.

Local population trends followed those of the relevant flyways for most species, most importantly for fisheating birds, ducks and greater flamingo. When local and flyway trends are similar, Messolonghi is assumed to be following a supra-local, more geographically widespread trend. On the other hand, dissimilarities have also been observed, especially for small waders, with local numbers increasing contrary to the declining flyway trends. It might be that ecological conditions have become better for selected species at Messolonghi relative to those at other sites or vice versa.

Overall, this study presented population estimates for 28 waterbird species wintering at Messolonghi, revealed an increasing trend of the species assemblage and confirmed the site's international importance for waterbirds during the last three decades. Such information could help managers make better decisions and could also be used as a basis for future comparisons with both local and flyway populations.

\section{Competing interests}

The authors declare that they have no competing interests.

\section{Authors' contributions}

$V L$ participated in midwinter counts, performed the statistical analysis and drafted the manuscript. FP and YR participated in the design of the monitoring scheme and in midwinter counts and also contributed to the methodology and discussion of findings. IP participated in the statistical 
analysis and contributed to the discussion of findings. All authors read and approved the final manuscript.

\section{Acknowledgements}

The present article was prepared after permission from the Hellenic Ornithological Society. We thank H. Visser, RIVM, for providing us with TrendSpotter software for the analysis of our data. We are very grateful to all the HOS staff and the volunteer ornithologists who were involved in midwinter counts, for without them this paper could not have been possible, and especially A. Athanassopoulos, M. Vassileiou, A. Christopoulos, A. Evangelidis, J. Fric, A. Galanaki, G. Handrinos, P. Hansen, A. Joensen, A. Kaltsis, L. Katerinopoulos, T. Kominos, J. Madsen, K. Papakonstantinou, D. Portolou, N. Preuss, T. Sarlis and M. Tzali. We also thank A. W. Lauder for the language editing and two anonymous reviewers whose comments and suggestions helped greatly improve the manuscript.

\section{Author details}

'Department of Forestry and Natural Environment Management, Eastern Macedonia and Thrace Institute of Technology, 1st km Drama-Mikrohori, Drama 66100, Greece. ${ }^{2}$ Ornithological Surveys, Aitoliko 30400, Greece. ${ }^{3} 40$ Almyraki str., Messolonghi 30200, Greece.

\section{Received: 8 November 2013 Accepted: 6 February 2014} Published: 19 February 2014

\section{References}

Athanassiou H (1987) Past and present importance of the Greek wetlands for wintering waterfowl. International Waterfowl Research Bureau (IWRB), Slimbridge

Atkinson PW, Austin GE, Rehfisch MM, Baker H, Cranswick P, Kershaw M, Robinson J, Langston RHW, Stroud DA, Van Turnhout C, Maclean IMD (2006) Identifying declines in waterbirds: the effects of missing data, population variability and count period on the interpretation of long-term survey data. Biol Conserv 130:549-559

Balkiz Ö, Özesmi U, Pradel R, Germain C, Sikl M, Amat JA, Rendón-Martos M, Baccetti N, Béchet A (2007) Range of the greater flamingo, Phoenicopterus roseus, metapopulation in the Mediterranean: new insights from Turkey. J Ornithol 148:347-355

BirdLife International (2004) Birds in Europe: population estimates, trends and conservation status. BirdLife Conservation Series No. 12. BirdLife International, Wageningen

BirdLife International (2012) Pelecanus crispus. In: IUCN 2012. IUCN red list of threatened species. Version 2012.2. http://www.iucnredlist.org. Accessed 15 Oct 2013

Burton NHK, Rehfisch MM, Clark NA (2002) Impacts of disturbance from construction work on the densities and feeding behavior of waterbirds using the intertidal mudflats of Cardiff Bay, UK. Environ Manage 30:865-871

Calbrade NA, Holt CA, Austin GE, Mellan HJ, Hearn RD, Stroud DA, Wotton SR, Musgrove AJ (2010) Waterbirds in the UK 2008/09: the wetland bird survey. BTO/RSPB/JNCC in association with WWT, Thetford

Catry T, Alves JA, Andrade J, Costa H, Dias MP, Fernandes P, Leal A, Lourenço PM, Martins RC, Moniz F, Pardal S, Rocha A, Santos CD, Encarnação V, Granadeiro JP (2011) Long-term declines of wader populations at the Tagus estuary, Portugal: a response to global or local factors? Bird Conserv Int 21:438-453

Crivelli A, Catsadorakis G, Hatzilacou D, Nazirides T (1997) Pelecanus crispus Dalmatian pelican. Birds of the Western Palearctic Update 1:149-153

Crowe O, Austin GE, Colhoun K, Cranswick PA, Kershaw M, Musgrove AJ (2008) Estimates and trends of waterbird numbers wintering in Ireland, 1994/95 to 2003/04. Bird Study 55:66-77

Dalby L, Fox AD, Petersen IBK, Delany S, Svenning J-C (2013) Temperature does not dictate the wintering distributions of European dabbling duck species. Ibis 155:80-88

de Nobel WT (ed) (1995) Birds of the Messolonghi wetlands. Eastern Mediterranean Wader Project, spring 1990. WIWO-report 53, Zeist, the Netherlands

del Hoyo J, Elliot A, Sargatal J (1992) Ostrich to ducks. Handbook of the birds of the world, vol 1. Lynx Edicions, Barcelona

Fouque C, Guillemain M, Schricke V (2009) Trends in the numbers of coot Fulica atra and wildfowl Anatidae wintering in France, and their relationship with hunting activity at wetland sites. Wildfowl 2:42-59

Gill FB (1994) Ornithology, 2nd edition. Freeman, New York
Handrinos G, Akriotis T (1997) The birds of Greece. Christopher Helm, London

Hustings F, Koffijberg K, Van Winden E, Van Roomen M, Zwanenwerkgroep SOVONG-e, Soldaat L (2009) Water birds in the Netherlands in 2007/2008. SOVON monitoringrapport 2009/02. Waterdienst-rapport SOVON Vogelonderzoek Nederland, Beek-Ubbergen. in Dutch with English summary

IUCN (2012) IUCN red list of threatened species. Version 2012.1. http://www. iucnredlist.org. Accessed 15 Oct 2013

Kear J (2005) Species accounts (Cairina to Mergus). Ducks, geese and swans, vol 2. Oxford University Press, Oxford

Kushlan JA, Hancock JA (2005) The herons. Oxford University Press, Oxford

Laursen K, Frikke J (2006) Assessment of sustainable management of staging waterbirds in the Danish Wadden Sea. Wildfowl 56:152-171

Lehikoinen A, Jaatinen K, Vähätalo A, Clausen P, Crowe O, Deceuninck B, Hearn R, Holt CA, Hornman M, Keller V, Nilsson L, Langendoen T, Tománková I, Wahl J, Fox AD (2013) Rapid climate driven shifts in wintering distributions of three common waterbird species. Glob Chang Biol 19:2071-2081

Maclean IMD, Austin GE, Rehfish MM, Blew J, Crowe O, Delany S, Devos K, Deceucnick B, Günther K, Laursen K, Van Roomen M, Wahl J (2008) Climate change causes rapid changes in the distribution and site abundance of birds in winter. Glob Chang Biol 14:2489-2500

Marion L (2003) Recent development of the breeding and wintering population of great cormorants Phalacrocorax carbo in France - preliminary results of the effects of a management plan of the species. Vogelwelt 124(Suppl):35-40

Martos MR, Johnson AR (1996) Management of nesting sites for greater flamingos. Col Waterbirds 19:167-183

Mateo R, Belliure J, Dolz JC, Aguilar-Serrano JM, Guitart R (1998) High prevalence of lead poisoning in wintering waterfowl in Spain. Arch Environ Contam Toxicol 35:342-347

Melville DS, Shortridge KF (2006) Migratory waterbirds and avian influenza in the East Asian-Australasian flyway with particular reference to the 2003-2004 H5N1 outbreak. In: Boere GC, Galbraith CA, Stroud DA (ed) Waterbirds around the world. The Stationery Office, Edinburgh, pp 432-438

Michev T, Profirov L (2003) Midwinter numbers of waterbirds in Bulgaria: results from 25 years of mid-winter counts carried out at the most important Bulgarian wetlands. Pensoft, Sofia

Miltiadou M (2005) Wintering populations, breeding attempts and lead poisoning of the greater flamingo Phoenicopterus roseus on the salt lakes of Cyprus. Flamingo 13:31-35

Mix HM, Bräunlich A (2000) Dalmatian pelican. In: Reading RP, Miller B (ed) Endangered animals: a reference guide to conflicting issues. Greenwood, London, pp 78-83

Musil P, Musilova Z, Fuchs R, Polakova S (2011) Long-term changes in numbers and distribution of wintering waterbirds in the Czech Republic, 1966-2008. Bird Study 58:450-460

Newton I (1998) Population limitation in birds. Academic, London

Nilsson L (2008) Changes in numbers and distribution of wintering waterfowl in Sweden during forty years, 1967-2006. Ornis Svec 18:135-236

Pergantis F, Handrinos G (1992) A preliminary check-list of the birds of the Messolonghi wetlands (1860-1986) with seasonal occurrence and population data. Biologia Gallo-hellenica 19:89-112

Perrins CM, Lebreton J-D, Hirons GJM (1993) Bird population studies. Oxford University Press, Oxford

Podulka S, Rohrbaugh RJ, Bonney R (ed) (2004) Handbook of bird biology, 2nd edition. Ithaca, The Cornell Lab of Ornithology

Rose PM, Scott DA (1997) Waterfowl population estimates, 2nd edition. Wetlands International Publication 44, Wageningen

Scott DA, Rose PM (1996) Atlas of Anatidae populations in Africa and western Eurasia. Wageningen, Wetlands International

Shine C, Klemm C (1999) Wetlands, water and the law: using law to advance wetland conservation and wise use. IUCN, Gland

Snow DW, Perrins CM (1998) Non-passerines. The birds of the Western Palearctic, vol 1. Oxford University Press, Oxford

Soldaat L, Visser H, Van Roomen M, Van Strien A (2007) Smoothing and trend detection in waterbird monitoring data using structural time-series analysis and the Kalman filter. J Ornithol 148(Suppl):351-357

Van Eerden MR, Koffijberg K, Platteeuw M (1995) Riding on the crest of the wave: possibilities and limitations for a thriving population of migratory cormorants Phalacrocorax carbo in man-dominated wetlands. Ardea 83:1-9

Van Roomen M, Laursen K, Van Turnhout C, Van Winden E, Blew J, Eskildsen K, Günther K, Hälterlein B, Kleefstra R, Potel P, Schrader S, Luerssen G, Ens BJ 
(2012) Signals from the Wadden sea: population declines dominate among waterbirds depending on intertidal mudflats. Ocean Coast Manag 68:79-88 Visser H (2004a) Detection of environmental changes: description of the TrendSpotter software. Memorandum 007/2004. IMP, RIVM, Bilthoven Visser $\mathrm{H}$ (2004b) Estimation and detection of flexible trends. Atmos Environ 38:4135-4145

Wetlands International (2010) Guidance on waterbird monitoring methodology: field protocol for waterbird counting. Wetlands International Report. Wetlands International, Wageningen

Wetlands International (2012) Strategic framework and guidelines for the future development of the List of Wetlands of International Importance of the Convention on Wetlands (Ramsar, Iran, 1971), 2012 revision. Resolution XI.8 Annex 2. In: 11th meeting of the conference of the parties to the Convention on Wetlands (Ramsar, Iran, 1971). "Wetlands: home and destination", Bucharest, Romania, 6-13 July 2012

Wetlands International (2013) Waterbird population estimates. http://wpe. wetlands.org. Accessed 15 Oct 2013

Zalidis CG, Mantzavelas AL (ed) (1994) Inventory on Greek wetlands as natural resources (first approximation). Greek Biotope/Wetland Centre (EKBY), Thessaloniki

doi:10.1186/1810-522X-53-12

Cite this article as: Liordos et al:: Long-term population trends reveal increasing importance of a Mediterranean wetland complex

(Messolonghi lagoons, Greece) for wintering waterbirds. Zoological Studies 2014 53:12.

\section{Submit your manuscript to a SpringerOpen ${ }^{\circ}$ journal and benefit from:}

- Convenient online submission

- Rigorous peer review

- Immediate publication on acceptance

- Open access: articles freely available online

- High visibility within the field

- Retaining the copyright to your article

Submit your next manuscript at $>$ springeropen.com 